\title{
Neurofibroma in the retroperitoneum associated with neurofibromatosis type 1
}

\author{
Hiroaki Saito, ${ }^{1}$ Tsuyoshi Suda @ (1, ${ }^{1}$ Masako Kobayashi, ${ }^{2}$ Eiki Matsushita ${ }^{1}$
}

${ }^{1}$ Department of Internal Medicine, Kanazawa Municipal Hospital, Kanazawa, Japan ${ }^{2}$ Department of Pathology, Kanazawa Municipal Hospital, Kanazawa, Japan

\section{Correspondence to} Dr Tsuyoshi Suda; t.suda1112@gmail.com

Accepted 28 October 2021

Check for updates

C) BMJ Publishing Group Limited 2021. No commercial re-use. See rights and permissions. Published by BMJ.

To cite: Saito H, Suda T, Kobayashi M, et al. BMJ Case Rep 2021;14:e244364. doi:10.1136/bcr-2021-

244364

\section{DESCRIPTION}

A 71-year-old woman presented with epigastric pain after having meals visited our hospital. On examination, she was diagnosed with gallstone cholecystitis, complicated with common bile duct stones.

She was treated appropriately, and her conditions improved. It was fortuitously noted that she had a retroperitoneal mass with a maximum diameter of $>10 \mathrm{~cm}$ surrounding the abdominal aorta (figure 1A).

However, she had no associated symptoms.

Considering this finding, we repeated the physical examination and medical interview. Several neurofibromas and café-au-lait spots were noted on the body, and a detailed interview revealed that she had been diagnosed with neurofibromatosis type 1 (NF1) previously (figure 1B). Contrast-enhanced CT showed a mild contrast around the mass. Positron emission tomography/ CT (PET/CT) showed mild accumulation of the mass: the maximum standardised uptake value $\left(\mathrm{SUV}_{\max }\right)$ was 3.7. Therefore, we assumed that the mass was a neurofibroma associated with NF1; however, we could not exclude the possibility of a malignant peripheral nerve sheath tumour (MPNST) based on imaging studies alone. Therefore, a tumour biopsy was performed simultaneously with laparoscopic cholecystectomy for a definitive diagnosis. The pathological diagnosis was confirmed as neurofibroma rather than MPNST because no positive findings for malignancy were observed (figure 2).

Until 4 years after the biopsy, the patient has been followed-up by imaging, and the neurofibroma in the retroperitoneum has been stable in size.

MPNSTs can arise from any neurofibroma, regardless of location, and patients with NF1 may have MPNSTs, especially in the retroperitoneum. ${ }^{1}$ The prognosis of MPNSTs may be poor because of their rapid growth and the possibility of distant metastasis. ${ }^{2}$ Furthermore, retroperitoneal tumours rarely present with specific symptoms, and delayed diagnosis is one of the factors for poor prognosis. ${ }^{23}$ The lifetime risk of developing MPNST in patients with NF1 patients is estimated to be $8 \%-13 \%{ }^{4}$ Although it is difficult to predict the occurrence of MPNST, it should be noted that MPNST is more common in adolescents, and symptoms such as pain may occur. Furthermore, imaging studies may show a rapidly enlarging mass. ${ }^{56}$ International guidelines, such as the European Society for Medical Oncology, recommend performing a core-needle CT scanguided biopsy for diagnosis, and surgical resection

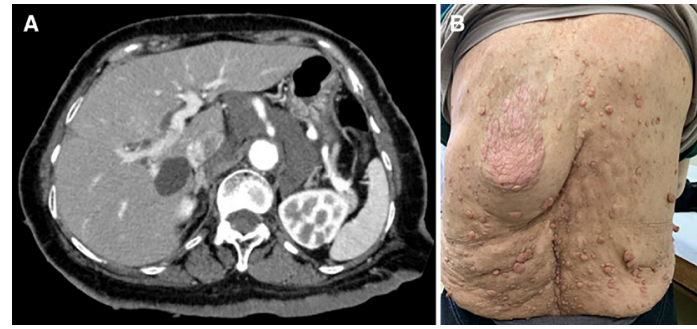

Figure 1 (A) Contrast-enhanced CT scan indicating a retroperitoneal mass around the abdominal aorta. (B) Numerous neurofibromas appearing on the back.

of the tumour is recommended for MPNSTs even if they are asymptomatic. ${ }^{27}$

A report involving imaging studies suggested the possibility of MPNST in the presence of two or more of the following four findings: intratumoural cystic lesion, largest dimension $>10 \mathrm{~cm}$, peripheral enhancement pattern and perilesional oedema-like zone. ${ }^{8}$ Our patient presented with two features: largest dimension $>10 \mathrm{~cm}$ and peripheral enhancement pattern, which led to the suspicion of MPNST. In contrast, another report suggested that malignancy should be considered when $\mathrm{SUV}_{\max }$ exceeds 4.8 on PET/CT. ${ }^{9}$ In our patient, the $\mathrm{SUV}_{\max }$ was 3.7; therefore, we did not suspect malignancy.

Since the results of MRI and PET/CT were difficult to diagnose, we performed a biopsy to produce an early diagnosis. Some reports indicate that diagnosis based on imaging studies alone is generally difficult, and careful pathological examination is necessary. ${ }^{410}$

If a neoplastic lesion is observed in a patient with NF1 and is strongly suspected to be malignant on imaging studies such as PET/CT, pathological examination should be performed at an early stage and surgical resection should be considered, despite the risk of invasiveness.

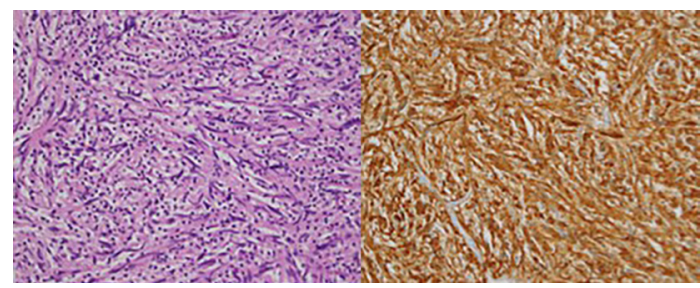

Figure 2 Histological samples showing spindle-shaped cells, although no increase in cell density or mitosis was observed, and immunohistochemical staining showing positivity for S-100 protein, leading to the diagnosis of neurofibroma. 
- Neurofibromatosis type 1 may be associated with retroperitoneal tumours, among which malignant peripheral nerve sheath tumour (MPNST) is highly malignant, with rapid progression and the possibility of metastasis.

- Retroperitoneal tumours are less likely to cause symptoms and may be detected incidentally on imaging examinations.

- A pathological diagnosis should be considered necessary, and the patient should be closely followed because there is a possibility of malignant retroperitoneal tumours, such as MPNST.

Contributors HS edited the manuscript and prepared the figures. TS cared for the patient, edited the manuscript and obtained the written informed consent from the patient. MK made the pathological diagnosis, edited the manuscript and prepared the figures. EM edited the manuscript and gave expert opinions on this case.

Funding The authors have not declared a specific grant for this research from any funding agency in the public, commercial or not-for-profit sectors.

Competing interests None declared.

Patient consent for publication Consent obtained directly from patient(s). Provenance and peer review Not commissioned; externally peer reviewed.

Case reports provide a valuable learning resource for the scientific community and can indicate areas of interest for future research. They should not be used in isolation to guide treatment choices or public health policy.
Tsuyoshi Suda http://orcid.org/0000-0001-9608-0444

\section{REFERENCES}

1 Yotsuya K, Hasegawa T, Yamato Y, et al. Retroperitoneal neurofibroma and a malignant peripheral nerve sheath tumor with neurofibromatosis type 1: a report of two cases. Spine Surg Relat Res 2020;4:369-73.

2 D'Agostino AN, Soule EH, Miller RH. Primary malignant neoplasms of nerves (malignant NEURILEMOMAS) in patients without manifestations of multiple neurofibromatosis (von Recklinghausen's disease). Cancer 1963;16:1003-14.

3 Cavallaro G, Basile U, Polistena A, et al. Surgical management of abdominal manifestations of type 1 neurofibromatosis: experience of a single center. Am Surg 2010;76:389-96.

4 Evans DGR, Baser ME, McGaughran J, et al. Malignant peripheral nerve sheath tumours in neurofibromatosis 1. J Med Genet 2002;39:311-4.

5 Riccardi VM. Von Recklinghausen neurofibromatosis. N Engl J Med 1981;305:1617-27.

6 Farid M, Demicco EG, Garcia R, et al. Malignant peripheral nerve sheath tumors. Oncologist 2014;19:193-201.

7 Casali PG, Abecassis N, Aro HT, et al. Soft tissue and visceral sarcomas: ESMOEURACAN clinical practice guidelines for diagnosis, treatment and follow-up. Ann Oncol 2018;29:iv51-67.

8 Wasa J, Nishida Y, Tsukushi S, et al. Mri features in the differentiation of malignant peripheral nerve sheath tumors and neurofibromas. AJR Am J Roentgenol 2010;194:1568-74.

9 Nose H, Otsuka H, Otomi Y, et al. Correlations between F-18 FDG PET/CT and pathological findings in soft tissue lesions. J Med Invest 2013;60:184-90.

10 Hughes MJ, Thomas JM, Fisher C, et al. Imaging features of retroperitoneal and pelvic schwannomas. Clin Radiol 2005;60:886-93.

Copyright 2021 BMJ Publishing Group. All rights reserved. For permission to reuse any of this content visit

https://www.bmj.com/company/products-services/rights-and-licensing/permissions/

BMJ Case Report Fellows may re-use this article for personal use and teaching without any further permission.

Become a Fellow of BMJ Case Reports today and you can:

- Submit as many cases as you like

- Enjoy fast sympathetic peer review and rapid publication of accepted articles

- Access all the published articles

- Re-use any of the published material for personal use and teaching without further permission

\section{Customer Service}

If you have any further queries about your subscription, please contact our customer services team on +44 (0) 2071111105 or via email at support@bmj.com.

Visit casereports.bmj.com for more articles like this and to become a Fellow 